\title{
THE INFLUENCE OF TOP MANAGEMENT TEAM ON CHINESE FIRMS' FDI
} AMBIDEXTERITY

\section{Yi Li ${ }^{1}$ and Lin Cui ${ }^{2}$}

${ }^{1}$ The University of Sydney, Australia, and ${ }^{2}$ The Australian National University, Australia

\begin{abstract}
Strategic ambidexterity has been under researched in the context of Chinese outward foreign direct investment (FDI). An ambidextrous FDI, balancing between exploratory and exploitive activities, is strategically desirable but managerially challenging. We examine the role of top management team (TMT) functional diversity in influencing Chinese firms' degree of FDI ambidexterity, and its boundary conditions in relation to the informal and formal institutional environments within which the TMT operates. Based on a panel of Chinese outward-investing manufacturing firms, our empirical analyses show that a marginal positive effect of TMT functional diversity on a firm's FDI ambidexterity is strengthened by the social faultline presence in the firm's TMT, but is weakened by the development of formal institutions in the firm's external environment.
\end{abstract}

KEYWORDS ambidexterity, China, foreign direct investment, functional diversity, institutional context, top management teams

Running title: The Influence of TMT on FDI Ambidexterity

Corresponding author: Yi Li (yi.li2@sydney.edu.au) 


\section{INTRODUCTION}

A growing body of literature on Chinese outward foreign direct investment (FDI) seeks to explore its unique characteristics that may contribute new theoretical insights to the FDI literature (Lu, Liu, \& Wang, 2011; Lyles, Li, \& Yan, 2014; Peng, 2012). Existing research has contrasted the strategic intent of competitive catch-up that drives exploratory FDI by Chinese firms (Cui, Meyer, \& Hu, 2014; Lyles et al., 2014) with the exploitative nature of conventional multinational corporations that internalize the transaction and deployment of existing competitive assets internationally (Dunning, 1988; Rugman, 1980). Recent studies suggest that exploratory and exploitative FDIs can be pursued ambidextrously for potential synergy from learning and profit-seeking activities (Luo \& Rui, 2009). In this study, we contribute to the understanding of Chinese outward FDI by examining the determinants of the investing firms' degree of FDI ambidexterity, namely, the balance between the exploratory and exploitative activities in their foreign subsidiaries (Hsu, Lien, \& Chen, 2013).

Despite its potential benefits, strategic ambidexterity incurs complexities in coordinating and synergizing exploratory and exploitative activities (Markides, 2013; Porter, 1996). From an upper-echelon perspective, the professional expertise and characteristic traits of a firm's top management team (TMT) provide cognitive and knowledge resources for complex strategic decision-making (Bantel \& Jackson, 1989; Wiersema \& Bantel, 1992). In line with this perspective, prior studies suggest that overcoming coordination challenges associated with strategic ambidexterity requires managerial capabilities of innovative and holistic problem solving by a functionally diversified top management team (TMT) (Barkema \& Shvyrkov, 2007; Cannella, Park, \& Lee, 2008; Carpenter \& Fredrickson, 2001). TMT functional diversity, defined as the degree to which TMT members differ with respect to their functional backgrounds (Cannella et al., 2008; Qian, Cao, \& Takeuchi, 2013), is therefore a key enabling factor of strategic ambidexterity. Extending this logic to the context of Chinese 
firms' FDI, we ask: what is the effect of TMT functional diversity on Chinese firms' FDI ambidexterity, and what contingency factors moderate that effect?

Based on the upper-echelon perspective, we discuss the mechanism underlying the main effect of TMT functional diversity on Chinese firms' FDI ambidexterity. We then integrate the upper-echelon perspective with new institutional economics to examine the contingency factors which moderate the main effect. Specifically, we argue that TMT functional diversity enables constructive task-related debate (Forbes \& Millliken, 1999), which allows the decision-makers to develop innovative and comprehensive solutions to complex coordinating and synergizing tasks associated with FDI ambidexterity. We further argue that this mechanism of task-related debate is activated by the informal (socio-cultural rules) and formal (market-supporting rules) institutional context in which the TMT operates. We find empirical support for our arguments from the analyses of a panel of Chinese outward investing firms over a five-year period. Our findings suggest that while TMT functional diversity can potentially enable FDI ambidexterity, that potential is more likely to be realized when the TMT features a strong social faultline presence, and when the formal marketsupporting institutions are less developed in the firm's external environment.

This study makes two main contributions. First, it contributes to the literature of Chinese outward FDI by examining the enabling factors of FDI ambidexterity. This literature acknowledges the potential benefits and the challenges of pursuing FDI ambidexterity (Luo \& Rui, 2009), especially given the bottleneck of managerial resources and capabilities of Chinese firms (Cui, Li, Meyer, \& Li, 2015; Meyer \& Xin, 2017). However, it remains unclear why certain Chinese firms can pursue FDI ambidexterity while others cannot. Our study reveals TMT functional diversity as an essential trait of the TMT that enables FDI ambidexterity, and the conditions under which this trait can be activated. Second, this study contributes to the upper-echelon perspective of organizational research by integrating this 
perspective with the new institutional economics. The role of the 'upper echelon' in firm strategic decision-making, although generally considered influential, has its boundaries. Managers are necessarily constrained by the formal and informal rules imposed on their organizations (Cui et al., 2015; D’Aveni \& Kesner, 1993). Our findings highlight the informal and formal institutional contingencies as the trait-activating conditions that are essential to the influence of managers on firm strategic decisions.

\section{THEORETICAL BACKGROUND AND HYPOTHESES}

\section{Exploratory FDI, Exploitative FDI, FDI Ambidexterity}

FDI allows firms to organize value chain activities (such as R\&D, supply, production and sales) across countries (Dunning \& Lundan, 2008; Rugman \& Verbeke, 2009). Conventional FDI theories suggest that FDI provides a governance structure to internalize the transaction of firm-specific assets (Caves, 1971; Hymer, 1976), which in turn, allows the firm to efficiently exploit the associated advantages internationally. For manufacturing firms, such exploitative FDI is commonly pursued for resource-seeking, market-seeking, and/or efficiency-seeking purposes, where the key objective is to maximize the return of, rather than enhancement of, the investing firms' existing core competencies (Dunning \& Lundan, 2008; Pananond, 2015).

Recent development in the FDI literature, echoing the rising phenomenon of FDI from emerging economies such as China, highlights an asset-seeking motivation of FDI in which firms aim to catch up with global market leaders by exploring foreign strategic factor markets (Cui et al., 2014). Such exploratory FDI with strategic asset-seeking motive is structured and executed for learning and developmental purposes (Wang \& Ahmed, 2007), and does not focus on exploitation of existing firm-specific advantages (Hsu et al., 2013). Following these prior studies, we define exploratory FDI as FDI that performs asset-seeking activities that enhance the investing firm's core competencies, whereas exploitative FDI 
typically performs resource-seeking, market-seeking, and/or efficiency-seeking activities to maximize the return of the investing firm's existing advantages.

FDI ambidexterity refers to the simultaneous pursuit of exploratory and exploitative FDI activities, which can potentially generate synergy between such activities (Hsu et al., 2013; Luo \& Rui, 2009). Strategic ambidexterity allows for advantage building and advantage leveraging concurrently (Knudsen \& Madsen, 2002; Luo, 2002; Teece, 2010), can speed up a firm's organizational learning (Kim, Mahoney, \& Tan, 2015), and better position the firm in a dynamic competitive environment (Barkema \& Drogendijk, 2007; Kim et al., 2015). However, FDI ambidexterity also presents unique managerial challenges. While exploitation often focuses on refinement, efficiency, selection, and implementation, exploration usually emphasizes search, variation, experimentation, and discovery (March, 1991; Raisch \& Birkinshaw, 2008). These two types of activities require different organizational resources and structures (Hsu et al., 2013; Ireland \& Webb, 2007). In the context of FDI, these challenges of ambidexterity are further magnified by the barriers of coordinating operations across national borders, known as the liabilities of foreignness (Zaheer, 1995), because the international coordination challenge increases with the variety of a firm's international business strategy (Lu \& Beamish, 2004).

\section{Upper-Echelon Perspective, TMT Functional Diversity, and Degree of FDI Ambidexterity}

Managing FDI ambidexterity is particularly challenging for firms lacking prior experience of coordinating cross-border operations, and it therefore requires a high level of innovative and holistic problem-solving capabilities in the TMT. The role of the TMT, especially their characteristics, in explaining firm strategic choices is highlighted in the literature of the upper-echelon perspective (Hambrick \& Mason, 1984). A central tenet of this perspective is that demographic characteristics (such as functional background) are strong indicators of 
individual skills, values, cognitive styles, and experiences (e.g., Jackson, 1992; Jehn, Northcraft, \& Neale, 1999). Accordingly, the characteristic traits of the TMT are powerful predictors of firm strategic choices.

Facing complex managerial challenges, such as strategic ambidexterity, TMT functional diversity plays an essential role in enabling team creativity and likelihood of innovative problem-solving (Bantel \& Jackson, 1989; Wiersema \& Bantel, 1992). TMT functional diversity can potentially facilitate firms' international expansion through enhanced problem-solving capabilities in unfamiliar situations (Bantel \& Jackson, 1989; Barkema \& Shvyrkov, 2007; Wiersema \& Bantel, 1992). However, the notion of TMT functional diversity enabling better decision-making is not without challenge. Specifically, sociocognitive conflicts (such as communication barriers and affective conflicts) from TMT diversity may incur process losses and undermine the extended cooperative efforts necessary for effective strategy (Ancona \& Caldwell, 1992; Carpenter, Geletkanycz, \& Sanders, 2004; Miller, Burke, \& Glick, 1998). Therefore, the mechanisms linking TMT functional diversity and strategic choice need to be explicated in the context of the given decision task (Hambrick, Cho, \& Chen, 1996; Miller et al., 1998).

In the context of pursuing FDI ambidexterity, we argue that functional diversified TMT has a larger knowledge pool for strategic decision-making than does a homogeneous team, given the complementary intellectual resources from heterogeneous functional backgrounds (Carpenter et al., 2004). Task-related debate, as a mechanism triggered by TMT functional diversity, facilitates team members in sharing and integrating their diverse knowledge to search for innovative and holistic solutions to the challenges posed by FDI ambidexterity. Upper-echelon research suggests that task-related debate among firm decisionmakers is likely to emerge if the diversity in the decision-makers' experiences, skills, values and beliefs relates directly to the decision task (Lovelace, Shapiro, \& Weingart, 2001; Pelled, 
Eisenhardt, \& Xin, 1999). Through task-related debate, the TMT can combine a variety of knowledge, perspectives and skill-sets that the overall team brings to bear in a decision situation (Cannella et al., 2008). Task-related debate can help a functionally diversified TMT generate more alternatives in order to creatively solve complex problems, reduce 'groupthink', and ultimately promote the effectiveness of the decisions made (Carpenter et al., 2004; Doz \& Kosonen, 2007). Thus, differences in functional background are more likely to surface in debate and become salient in TMT decision-making (Forbes \& Millliken, 1999). Applying the upper-echelon perspective of TMT functional diversity to foreign market entry, prior research suggests that functionally diversified TMTs, with their complementary knowledge and rigorous decision-making, have the advantage of generating innovative solutions to alleviate foreign market entry barriers and enhance post-entry coordination effectiveness, and these enable the investing firm to better manage liabilities of foreignness when expanding into international markets (Barkema \& Shvyrkov, 2007).

For Chinese firms, TMT functional diversity allows them to identify and solve strategic differences regarding the task of pursuing exploration and exploitation simultaneously through ambidextrous FDI. Despite the potential synergy, undertaking ambidextrous FDI also incurs conflicting input demands, and it presents different requirements for resource allocation and organization structure for the simultaneous pursuit of exploitative and exploratory activities (Floyd \& Lane, 2000; March, 1991). Since exploration and exploitation are self-reinforcing, often to each other's exclusion (Levinthal \& March, 1993; March, 1991), they are likely to attract the TMT's attention, resulting in a strategic imbalance together with undesired compromises. TMT functional diversity is likely to provide the required managerial skills, strategic views and ways of understanding and executing ambidextrous FDI (Cao, Simsek, \& Zhang, 2010; Smith \& Tushman, 2005). Complementary knowledge and task-related debate enabled by functional diversity can help 
TMTs generate new ideas and utilize innovative approaches to solve internal tensions between exploration and exploitation when undertaking ambidextrous FDI (Jehn, 1997; Jehn et al., 1999). The advantage of diversity can help firms generate synergy between exploitative and exploratory activities (Luo \& Rui, 2009), and this then enables them to catch up with established multinational corporations.

While task-related debate with complementary knowledge works as the main mechanism for a positive effect of TMT functional diversity on Chinese firms' FDI ambidexterity, we acknowledge that affective conflict from a diversified team may dilute this positive effect. Hence, the debate mechanism does not necessarily imply a mediated causal effect, because, for some TMTs, such debate may incur decision-making barriers, as opposed to enhanced capability in dealing with strategic complexity. For instance, prior studies have discussed the mechanism of affective conflict associated with TMT functional diversity, which negatively influences decision-making quality by inducing tension or animosity between team members (Jehn, 1995; Qian et al., 2013). Because of the different logics that arise from their professional expertise and various interests in their functional focuses, TMT members may have difficulty in communicating effectively, correctly interpreting the motivation of each other, and reaching an agreement with mutually satisfying solutions (Amason, 1996; Eisenhardt \& Bourgeois, 1988). Affective conflict may compromise taskrelated debate with complementary knowledge by turning the nature of the debate from constructive knowledge sharing and integration to destructive quarrelling (Amason, 1996; Tjosvold, Law, \& Sun, 2006).

In the context of FDI decision-making by TMTs, we argue that, although functional diversity may induce affective conflict, it is unlikely to dominate the dynamics of the professional and social interactions between TMT members. Top executives are typically highly experienced and qualified professionals who are unlikely to let their task-related debate 
be entirely biased by emotions. Moreover, while individual TMT members may identify with their respective functional and professional areas, their position in the upper echelon of the firm also suggests that they tend to have strong organizational identification, and the alignment of their individual identities to the firm can smooth some negative emotions that may arise from their separate functional identities. While the extent to which affective conflict dilutes the mechanism of task-related debate with complementary knowledge is ultimately an empirical question, we propose the following hypothesis as a baseline argument for the main effect of TMT functional diversity on Chinese firms' FDI ambidexterity:

\section{Hypothesis 1: TMT functional diversity will be positively related to Chinese firms' degree of FDI ambidexterity.}

\section{Informal and Formal Institutional Contingencies of TMT Effect}

Upper-echelon research suggests that the diverse knowledge and information available in a functionally diversified TMT need to be frequently and effectively exchanged and integrated before they can be utilized to support decision-making (Boone \& Hendriks, 2009; Lee \& Park, 2006). The social process of behavioral integration among TMT members is necessarily shaped by the informal and formal institutional environments in which the TMT operates; these impose rules that constrain or enable TMT members to engage in information exchange and constructive debate with each other. Based on North's (1990) argument, institutions are humanly-devised constraints that structure political, economic, and social interactions. Such constraints can be informal, in the form of cultural and social norms, and formal, such as regulations and laws.

Integrating the upper-echelon reasoning with the institutional contingencies informed by new institutional economics, we argue that the mechanisms underlying the main effect of TMT functional diversity are contingent on the cultural/social and economic constraints on TMT 
members. While functional diversity provides the potential for TMT members to engage in taskrelated debate with complementary knowledge, the actual debate is activated by the informal (socio-cultural rules) and formal (market-supporting rules) institutional context in which the TMT operates. These rules give TMT members social and economic incentives to engage in constructive task-related debate by reducing their concerns over power hierarchy and job security.

First, the informal institutional environment involves the socio-cultural impact on behavioral integration among TMT members of Chinese firms. TMT members may perceive less incentive to engage in opinionating and task-related debate if the cultural norm of the TMT penalizes individualism while promoting group harmony. In the Chinese context, the collectivistic cultural norm and high power distance between individuals are two important informal rules that structure individual behavior in almost all levels of social interactions (Harzing, Brown, Koster, \& Zhao, 2012). These two cultural features lead to two barriers for functionally diversified TMT members to engage in genuine and constructive task-related debate. The first barrier is the power hierarchy in the TMT induced by a high power distance culture. With high power distance, individuals have strong tendency to submit to authority, rather than voice differing opinions. The second barrier is the collective cultural norm. Within a collective culture, individuals value group coherence and harmony and therefore are unlikely to challenge each other (Tjosvold, Poon, \& Yu, 2005).

While embedded in the national cultural context described above, individual Chinese firms, and their TMTs, can deviate from this national cultural baseline to various degrees. Within a national cultural system, subcultures exist across age groups, genders, regions, education, and economic status, among other demographic factors (Dau, 2016; Minkov \& Hofstede, 2012). As a process of social categorization, individuals in a social group develop their unique cultural identity that distinguishes them from other groups. The more distinctive a group culture is, the 
more it deviates from the collective national culture, and the less the group members are influenced by the latter. This social categorization process takes place within the organization (Ellemers, \& Rink, 2005), including the upper echelon of the firm. For instance, research shows that social categorization in a TMT can create division between homogeneous subgroups (Barkema \& Shvyrkov, 2007). This phenomenon is identified by Lau and Murnighan (1998) as TMT faultline setting, the process by which TMTs divide themselves into subgroups based on demographic attributes.

A strong demographic faultline in a TMT indicates that members of the TMT form clearly divided and characteristically distinctive subgroups. Such a faultline allows the TMT to deviate from the national cultural baseline and, as a result, to overcome the two cultural barriers that compromise knowledge sharing and integration through task-related debate. Because of social categorization, TMT members with faultline presence have strong identification with their subgroups, rather than identifying the organization or TMT as a whole. Furthermore, to the extent that a subgroup is demographically distinct from the other subgroup(s) in the TMT, its members focus their social identification on the subgroup, receive identity support from it, and thus become less influenced by the collective norm of the whole team. Studies show that individuals in one subgroup perceive within-group affective support and gain psychological confidence to voice disagreement with members in other subgroup(s) (Hutzschenreuter \& Horstkotte, 2013; Posthuma \& Campion, 2009).

Not only does the social faultline allow members of the TMT to deviate from the collective norm of the national cultural baseline, it also imposes multiple logics on the upper echelon of the firm, which lead to an ideal environment for task-related debate. Institutional theorists argue that the acceptance of multiple logics in a group is contingent on the relative power of group members (Besharov \& Smith, 2014). A logic is more likely to be embodied in core organizational practices when group members carrying that logic have more power in the 
organization (Kim, Shin, Oh, \& Jeong, 2007). It follows that when subgroups in the organization have (somewhat) equal power, the acceptance of multiple logics will be increased in organizational practices (Besharov \& Smith, 2014). In our context, social grouping from a demographic faultline reduces power distance and increases the power equality in TMTs of Chinese firms, which makes these TMTs more tolerant of different ideas or logics.

Overall, compared to a TMT with a homogenous demographic composition of members, a TMT with a demographic faultline can better bridge the power distance within the TMT, reduce the incentives to maintain collective harmony in the team, lower the social and psychological constraints on opinion expression and task-related debate, and, ultimately, strengthen the knowledge advantages of a functionally diverse TMT. Accordingly, we hypothesize:

Hypothesis 2: TMT demographic faultline presence will positively moderate the effect of TMT functional diversity on Chinese firms' degree of FDI ambidexterity.

Second, apart from informal institutions, the level of formal institutional development in the external environment may also influence how TMTs function (Qian et al., 2013). Specifically, the economic incentives for TMT members to engage in knowledge sharing and task-related debate to improve strategic decision-making are higher when the costs of external knowledge search are greater, leaving firms with less cost-efficient alternatives to an internal knowledge pool.

The role of the home institutional environment on firm strategy formulation and implementation is particularly prominent in the Chinese context (Cui, 2016; Peng, Wang, \& Jiang, 2008). The development level of formal market-supporting institutions can vary across subnational regions within an emerging economy such as China (Shi, Sun, \& Peng, 2012). 
Extensive 'voids' in formal market-supporting institutions increase information asymmetry and transaction costs of the external market, which may constrain Chinese firms' external knowledge- and information-seeking efforts, because the external market for managerial resources and professional expertise is underdeveloped and inefficient. With external market failure, limited knowledge sources of vicarious learning and dysfunctional market intermediaries motivate Chinese firms to resort to grafting learning, whereby they rely on internal managerial expertise to manage internationalization (Cui et al., 2015). This situation will encourage firms to rely more on internal sources of information and knowledge, which are relatively more efficient than external ones (Khanna \& Palepu, 2006). As such, firms depend more on the internal knowledge pool of their TMTs for strategy formulation and operation. Apart from making firms more dependent on internal knowledge sources, underdeveloped formal institutions also incur greater environmental uncertainties. Underdeveloped institutions can hinder information availability and incur high transaction costs, which increase uncertainty for Chinese firms' operations. In an unstable environment, executives are granted greater discretion for firms' strategic decision-making (Finkelstein \& Hambrick, 1990; Haleblian \& Finkelstein, 1993). As such TMT members are incentivized to engage with their decision-making roles, they are more likely to induce task-related debate (Carpenter \& Fredickson, 2001; Carpenter \& Sanders, 2004), which is crucial to generate new ideas and approaches to handle challenging decision tasks (Karasek, 1979).

Overall, voids in formal market-supporting institutions incentivize TMT members to engage in knowledge sharing and constructive task-related debate with each other, as opposed to replying on external knowledge sources such as consultancy or vicarious learning from other firms. Therefore, a functionally diversified TMT has a greater role in contributing to complex strategy (such as ambidextrous FDI) in an external environment with a low level of formal institutional development. Accordingly, we hypothesize: 
Hypothesis 3: Formal institutional development will negatively moderate the effect of TMT functional diversity on Chinese firms' degree of FDI ambidexterity.

\section{METHODS}

\section{Sample and Data}

We tested our hypotheses in the context of outward FDI from China. Following prior studies in the literature on Chinese FDI, we focus on manufacturing sectors (2-digit SIC Codes: 20 to 39) which generate a major proportion of Chinese outward FDI (Wang, Hong, Kafouros, \& Wright, 2012), and on listed firms as good representatives for their accelerated internationalization activities (Cui et al., 2015). Accordingly, our sampling frame consists of all Chinese listed manufacturing firms during 2005-2010, to which we further applied two sampling criteria. First, following Hitt, Hoskisson, and Kim (1997), we chose firms with at least \$US50 million in market capitalization, to ensure that our sample firms (1) have an adequate size to potentially achieve the strategic objectives of ambidextrous FDI, and (2) have more complete and accurate data that are publicly available. Second, to examine the degree of FDI ambidexterity, a sample firm is required to have FDI operations. We excluded investments in offshore tax havens, which are a main source of capital flight that biases FDI statistics of China (Morck, Yeung, \& Zhao, 2008). After adopting a one-year lag and deleting cases with missing data, we obtained an unbalanced panel of 127 firms over five years, with 374 firm-year observations.

Archival data were collected from Orbis and Wind databases, which are commonly used sources of research on Chinese outward FDI (Cui \& Jiang, 2012; Zou \& Adams, 2008). To supplement these databases, we manually identified TMT members of a firm from annual reports by following prior studies (e.g. Boeker \& Wiltbank, 2005; Nielsen \& Nielsen, 2013), 
and collected their demographic data from firm annual reports. Industrial and institutional indicators were sourced from the National Bureau of Statistics of China database and the National Economic Research Institute (NERI) database (Fan, Wang, \& Zhu, 2007).

\section{Adjusting for Self-Selection}

As a part of our sampling strategy, we retained firm-year observations where the firm had FDI operation in a given year. However, firms that have conducted FDI could have unobserved resources and capabilities that are systematically different from those without FDI and are thus excluded from the sample, raising concern about sample selection-induced endogeneity (Yang, Lin, \& Lin, 2010). To deal with this, we employed Heckman's two-step selection approach that predicts the likelihood of sample-selection bias using a probit regression. The inverse Mills ratio from the probit regression was used as a predictor in the second stage regression analysis for hypothesis testing.

The first stage selection model was estimated on a panel dataset of all Chinese listed manufacturing firms meeting the size criterion from 2005 to 2010, which resulted in a oneyear lag panel of 603 firms with 2193 observations after removing observations with missing data. The first stage probit model had a dependent variable of one if a firm has FDI in a given year, or zero if otherwise. We included three exclusion restrictions in the first stage model. First, industry rate of globalization change (measured as the rate of world export value divided by world production output in the given industry with 4-digit SIC code) may motivate Chinses firms to engage in outward FDI to comply with the trend of industry development in the world. While this variable is likely to influence firms' FDI propensity, it is unlikely to determine firms' degree of FDI ambidexterity, as it is not definitely clear that firms responding to globalization will prefer strategic ambidexterity. Second, the Chinese government continuously introduces and modifies its FDI regulations to influence Chinese 
firms' internationalization. Thus, we use key FDI regulations in China (measured as the total number of key FDI regulations in China in a given year) to represent home-country institutional effects on Chinese firms' FDI propensity. Since the governmental regulations do not explicitly incentivize certain strategic types, this variable is not included in second stage model. Third, we include foreign exchange rate (measured by average RMB/USD exchange rate in a given year) in our first stage model, because it affects the costs of setting up foreign subsidiaries, without differentiating the strategic types of their activities. To validate the choice of these three exogenous variables, we tested the Pearson pair-wised correlation between degree of FDI ambidexterity and the abovementioned variables, and found no significant correlation between any of them.

\section{Variables}

Degree of FDI ambidexterity. Our dependent variable is measured by following the organizational ambidexterity calculation in prior studies (see Cao, Gedajlovic, \& Zhang, 2009; He \& Wong, 2004):

$$
\text { Degree of FDI Ambidexterity = } 1-\mid \text { Exploration\% } \% \text { Exploitation\% } \mid
$$

Where

$$
\begin{aligned}
& \text { Exploration } \%=\frac{\text { Total Assets of Exploratory Foreign Subsidiaries }}{\text { Total Assets of All Foreign Subsidiaries }} \\
& \text { Exploitation } \%=\frac{\text { Total Assets of Exploitative Foreign Subsidiaries }}{\text { Total Assets of All Foreign Subsidiaries }}
\end{aligned}
$$

We identified the exploratory/exploitative strategic orientation of sample firms' foreign subsidiaries based on the conceptualization of these strategic orientations in the international business context (Barkema \& Drogendijk, 2007; Katila \& Ahuja, 2002). Its operationalization needs to be context-specific, that is, what constitutes exploration or exploitation depends on the current competitive positioning of the investing firms and the 
activities of their foreign subsidiaries in relation to their core-competency (Hsu et al., 2013). In recent decades, China has becoming an important 'world factory' for a variety of products in multiple industries. Chinese companies have also developed their manufacturing capabilities to provide solutions in a wide range of value chain activities, and this has helped them to generate comparative advantage when operating in other developing-country markets. Some Chinese manufacturing firms may engage in natural resource-seeking activity through FDI. This type of activity cannot augment a firm's existing core competencies, but is more likely to be conducted for cost efficiency on the supply side to facilitate a firm's exploitation of existing strengths. However, most Chinese firms remain inferior to developed MNEs in key value-added activities (such as $R \& D$, marketing, and manufacturing activities). This drives Chinese firms to pursue exploration as a channel to catch up with their existing and potential global rivals (Cui et al., 2014). Accordingly, in this study, Chinese firms' FDI operations in OECD economies with main activities in R\&D, marketing, and/or manufacturing were identified as exploratory activities. All other FDI operations (including resource-seeking activity) were identified as exploitation.

TMT functional diversity. The TMT is defined as the executive team listed in Chinese firms' annual reports. While titles are not uniform in executive team sets, only executive members managing the firm's operations (based on their biographies in annual reports) were counted in this study. Based on their career path, we classified each TMT member's dominant functional expertise in (1) engineering/R\&D, (2) finance/accounting, (3) marketing/sales, (4) production/operations, (5) administration, (6) human resource management/labor relations, or (7) law practice. Following previous studies (e.g., Qian et al., 2013), we calculated TMT functional diversity with a Blau index (Blau, 1977). This index was calculated as $D=1-\sum_{i} P_{i}^{2}$, 
where $P_{i}$ is the proportion of TMT in the $i$ th functional category. $D$ varies between 0 and 1 . When the value closes to 1 , this indicates higher functional diversity among the TMT.

TMT faultline presence. Faultline research suggests two dimensions of faultline setting strength and distance (Bezrukova, Jehn, Zanutto, \& Thatcher, 2009; Zanutto, Bezrukova, \& Jehn, 2011). While strength measures how cleanly a group splits into two subgroups, distance measures how far apart these subgroups are on demographic characteristics. Zanutto et al. (2011) argue that the interaction of faultline strength and distance is the most influential predictor of faultline setting. Accordingly, we used the product of TMT faultline strength and distance to measure TMT faultline presence, based on four demographic characteristics - age, gender, education, and tenure in the TMT:

TMT Faultline Presence $=$ TMT Faultline Strength $\times$ TMT Faultline Distance We calculated faultline strength using the algorithm developed by Thatcher, Jehn and Zanutto (2003). Faultline distance was then calculated as the Euclidean distance between subgroup centroids: $D_{g}=\sqrt{\sum_{j=1}^{p}\left(X_{1 j}-X_{2 j}\right)^{2}}$. For detailed explanation of faultline-setting measurement, see Thatcher et al. (2003) and Zanutto et al. (2011).

Formal institutional development in sub-national regions. Following Shi et al. (2012), we adopted the province-level index of marketization developed by the NERI (Fan et al., 2007). The overall NERI index assesses annual institutional development of Chinese provinces on five categories: government and market forces; development of non-SOEs (state-owned enterprises); development of commodity markets; development of factor markets; and development of market intermediaries and a legal environment. We conducted a principal component analysis which suggested that one factor should be generated from these five categories during our observation period. On average, this factor can explain $71.56 \%$ of the 
total variance, and the average value of Kaiser-Meyer-Olkin measure is 0.749 . Therefore, we used the factor score to represent the time-variant formal institutional development level of Chinese provinces.

Control variables. A firm's international commitment may influence its resource distribution and competitive activities, which then affects the focal firm's FDI strategy (Nadkarni \& Perez, 2007). Thus, we used degree of internationalization, measured by a firm's foreign sales divided by its total sales, as a proxy to control for this effect. TMT size, namely, the total number of top executives in a TMT, may influence managerial resources (Hutzschenreuter \& Horstkotte, 2013) and consequently FDI ambidexterity. We also controlled for firm size, measured by the log-transformed value of a firm's total assets (in thousands of US dollars) (Cannella et al., 2008). Feedback from past performance may affect risk preference (Greve, 2003) and FDI strategy. Accordingly, we controlled for past performance using profit margin. We used a dummy variable to differentiate if a firm is affiliated with a business group, which may affect firm resources and governance related to FDI strategy (Estrin, Poukiakova, \& Shapiro, 2009). State-owned firms may have risk tolerance and strategic preference that differ from those of non-state-owned firms (Cui \& Jiang, 2012). We used a dummy variable to control state-owned enterprise. Other than direct state ownership, legalperson shareholding also plays prominent roles in Chinese listed firms, potentially influencing their strategy formulation and operations (Zou \& Adams, 2008). We summed equity ownership held by legal-person shareholders as a control variable. In addition, pyramidal ownership structure is commonly seen in emerging economy firms, which gives the ultimate shareholder a control right exceeding its cash-flow right (Claessens, Djankov, Fan, \& Lang, 2002). This excess control enables the ultimate shareholder to influence firm strategy in order to maximize self-interest (Cui et al., 2014). Thus, we controlled for a firm's 
ultimate shareholder excess control, measured as the difference between ultimate shareholders' voting rights and cash flow rights (Claessens et al., 2002). Lastly, at industry level, we also controlled for environmental munificence and environmental dynamism, which may influence Chinese firms' effectiveness in certain FDI strategies (Cao et al., 2009). These two variables were measured each year with moving five-year windows. Based on Keats and Hitt (1988) and Fernhaber and Patel (2012), we regressed a natural logarithm of industry sales on time. With log-transformed industry sales, unpredictable changes and high volatility were smoothed in the measure (Fernhaber \& Patel, 2012). Accordingly, we can anti-log transformed regression results to explain changes of industry sales before their logtransformation. For environmental munificence, we took the anti-log of beta as its measure, which represents the average industry growth rate over the five-year moving window. For environmental dynamism, we took the anti-log of the standard error of the beta. Higher standard errors indicate greater environmental discontinuities. All control variables are timevariant and one-year lagged.

\section{Analysis}

We used panel GLS regression analysis due to the panel structure of our data and the continuous dependent variables. Results from Breusch-Pagan Lagrange multiplier test indicated significant firm effects $(\mathrm{p}=0.000)$, suggesting that pooled GLS regression model is inappropriate. We conducted Hausman test for the choice between random-effect and fixedeffect models. The Hausman test examines the null hypothesis that the coefficients estimated by the random-effects estimator are the same as the ones estimated by the fixed-effects estimator. For the regression with degree of FDI ambidexterity variable, the results from the Hausman test indicated no difference in the coefficient estimates of the two models $(p=$ 0.454). Thus, we used the more efficient random-effects panel GLS regression model. We 
also adopted a one-year lag for all of our independent variable, moderators and controls during the analysis.

To rule out reverse causation for our main effect, we conducted the Granger causality test for panel datasets (Granger 1969; Luo, Wang, Raithel, \& Zheng, 2015), using EViews 9.0; this reported no substantial influence from degree of FDI ambidexterity to TMT functional diversity with one year lag $\left(F_{\text {Granger test }}=1.142, p=0.286\right)$, two years lag $\left(F_{\text {Granger test }}=1.085, p=0.340\right)$, and three years lag $\left(F_{\text {Granger test }}=1.136, p=0.337\right)$. These findings suggest that reverse causality is not evident in our data.

\section{RESULTS}

\section{Descriptive statistics}

Table 1 reports the descriptive statistics and correlation matrix for the explanatory variables. The variance inflation factors (VIFs) of explanatory variables are all below 5 (with mean VIF of 1.66), suggesting that multicollinearity is not of major concern in our models.

[INSERT TABLE 1 ABOUT HERE]

\section{Hypothesis Testing}

We estimated random-effects GLS regression models to test our hypotheses. Four models were tested for the dependent variable (degree of FDI ambidexterity), and the results are reported in Table 2 .

\section{[INSERT TABLE 2 ABOUT HERE]}

We tested our hypotheses in model 3 to model 5. All variables in the second stage tests (model 2 to model 5) were standardized. In model 2, we regressed all controls only in order to predict for FDI ambidexterity. 
In Hypothesis 1, we argue that a Chinese firm's TMT functional diversity is positively associated with its degree of FDI ambidexterity. In model 3, the standardized coefficient for TMT functional diversity was positive $(b=0.09)$ and had a p value of 0.085 . This result provides marginal support for our Hypothesis 1. As discussed above, the lack of statistical certainty in the main effect may be due to the existence of a parallel negative mechanism of affective conflict, which dilutes (although it does not completely revert) the positive mechanism of task-related debate. This marginally supported main effect leads to more importance of the subsequent tests of the moderating effects.

For the moderating effects, our Hypothesis 2 states that TMT faultline presence strengthens the relationship between TMT functional diversity and the Chinese firm's degree of FDI ambidexterity. In model 4, the interaction product term between TMT functional diversity and TMT faultline presence was positive $(b=0.10)$ and had a $\mathrm{p}$ value of 0.015 , supporting our Hypothesis 2. Following the practice of prior studies (e.g., Brambor, Clark, \& Golder, 2006; Chizema, Liu, Lu \& Gao, 2015), in order to determine the size of the moderating effect, we plotted the marginal effect of standardized TMT functional diversity on degree of FDI ambidexterity on the condition of standardized TMT faultline presence (Figure 1).

\section{[INSERT FIGURE 1 ABOUT HERE]}

As shown in Figure 1, the lower boundary of the 95\% confidence interval crosses the zero line when the value of standardized TMT faultline presence equals 0.24 , under which the marginal effect of TMT functional diversity on FDI ambidexterity is $0.104(0.08+0.1 \times$ 0.24). As TMT faultline presence increases from this point, the marginal effect of TMT functional diversity also increases while remaining in the significant region with a $95 \%$ confidence interval. However, when TMT faultline presence drops below 0.24 , the marginal effect of TMT functional diversity becomes indeterminant with the $95 \%$ confidence interval. 
These results show that the main effect (as stated in Hypothesis 1) is not always statistically significant, and its significance and effect size increase with the moderator TMT faultline presence. These results further support Hypothesis 2.

Hypothesis 3 states that formal institutional development negatively moderates the TMT functional diversity effect on a Chinese firm's ambidextrous FDI. As shown in model 5, the moderating interaction term of TMT functional diversity and formal institutional development was negative $(b=-0.11)$ and had a $\mathrm{p}$ value of 0.043 . As with the above calculation, we plotted the marginal effect along the range of this moderator, namely, formal institutional development (see Figure 2). Figure 2 shows a critical point of the moderator at the value of 0.31 , under which the marginal effect of TMT functional diversity is $0.106(0.14$ $-0.11 \times 0.31)$. When formal institutional development is under this critical value, the marginal effect of TMT functional diversity remains significant within the $95 \%$ confidence interval; and this marginal effect increases as the moderator decreases. However, when formal institutional development takes a value above 0.31 , the marginal effect of TMT functional diversity on FDI ambidexterity becomes indeterminant within the $95 \%$ confidence interval. Overall, these results show that the main effect of TMT functional diversity increases in significance and magnitude (effect size) when formal institutional development decreases. Hypothesis 3 is further supported.

\section{[INSERT FIGURE 2 ABOUT HERE]}

It is worth noting that the r-squares of our models were relatively low, indicating a large proportion of unexplained variance in the outcome variable. We speculate that organizational contexts for ambidexterity might be the reason for unexplained variance. Gibson and Birkinshaw (2004) suggest that contexts characterized by a combination of discipline, stretch, trust and support can facilitate organizational ambidexterity. Organizations achieving ambidexterity are expected to balance the hard elements (e.g., discipline, stretch) 
and the soft elements (e.g., trust, support) in their organizational contexts (Raisch \& Birkinshaw, 2008). While we have controlled for firm experience and financial resources as organizational supports for ambidextrous FDI, we were unable to fully control for the organizational contexts in this study because of limited data on engagement of departments and contextual information. Another potential explanation is that, given a relatively small sample $(n=374)$, the value of our moderators cannot cover their ranges in population, which may also limit explained variance in model 4 and model 5. Notwithstanding the relatively low r-squares, our results did support the significance of the incremental explanatory power contributed by the hypothesized main and moderating effects.

\section{Robustness Check}

We used alternative measurements of explanatory variables to test if the results are robust to operationalization. First, for the dependent variable, we used a dummy variable as alternative measure for Chinese firms' ambidextrous FDI. Firms had a value of 1 if they had both exploratory and exploitative FDI in a given year, or a value of 0 if otherwise. Second, for the independent variable, we replaced the Blau index measure with the entropy measure to calculate TMT functional diversity. For entropy measurement, this was calculated as $D=1$ $\sum_{i}\left(P_{i} \times \ln \left(1 / P_{i}\right)\right)$, where $P_{i}$ is the proportion of TMT in the $i$ th functional category. The higher value of entropy measure means higher functional diversity among the TMT. Third, while originally we used the interaction of TMT faultline strength and distance to represent TMT faultline presence, we included them as two separate moderators in the robustness test. Fourth, we used industrial output value rather than industry sales for the calculation of two industry-level control variables, namely, environmental munificence and dynamism. Fifth, we used development of institutional intermediaries as an alternative measure of formal institutional development, because home institutional intermediaries are important channels 
for Chinese firms seeking external knowledge sources. From the NERI index, four subindicators for intermediaries in professional expertise were extracted: financial expertise, technological expertise, legal and accounting expertise, and industry association expertise. As Cronbach's Alpha for these sub-indicators is 0.8064 , we integrated them with averaged value to measure development of institutional intermediaries. Lastly, we used ROA as an alternative measurement of firm's past performance instead of profit margin.

Results of the robustness test are reported in Table 3. As shown in model 8 and model 9, TMT faultline strength does not moderate the effect of TMT functional diversity on Chinese firms' ambidextrous FDI ( $b=0.78 ; p=0.185)$, while TMT faultline distance marginally moderates the main effect $(b=0.93 ; p=0.091)$ for ambidextrous FDI choice. In comparison to our main tests (Table 2), these results suggest that the two components of faultline presence, namely, strength and distance, have stronger predictive power when used interactively rather than separately, providing support to recent faultline setting research. Model 10 suggests that our moderating effect of institutional development is robust $(b=$ $-2.67 ; p=0.003$ ). All robustness test models returned results that are largely consistent with the original tests, indicating that the results are robust.

\section{DISCUSSION AND CONCLUSION}

This study examines the effect of TMT functional diversity on Chinese firms' FDI ambidexterity, a strategy that helps them achieve synergy between exploitative and exploratory activities. It adds new insights into the understanding of the enabling factors of FDI ambidexterity, while advancing theoretically the upper-echelon perspective by integrating this perspective with the new institutional economics. Our findings highlight that the positive effect of TMT functional diversity is contingent on the informal and formal institutional environments where Chinese firms are embedded. These contingencies may 
apply broadly to outward-investing firms originating from other emerging economies with a collectivism cultural orientation and continuous transition of formal institutions in their home country, within the limit of generalizing empirical research findings across different contexts (Meyer, 2015).

\section{Main Findings}

While the positive effect of TMT diversity on business strategy has been supported in the context of developed MNEs (e.g., Cannella et al., 2008; Carpenter \& Fredrickson, 2001), our study is the first to examine its conditional effect on ambidextrous FDI strategy in the context of emerging economy with institutional contingencies, which has become increasingly important for Chinese firms' survival and development in today's business environment (Luo \& Rui, 2009).

Drawing on the new institutional economics, our study examined informal and formal institutional environments of the TMT effect. For the informal institutional contingency, prior studies suggested that TMTs' willingness of information sharing and cooperation will decrease in a strong faultline presence, due to biased perceptions and potential affective conflicts between subgroups (e.g., Hutzschenreuter \& Horstkotte, 2013). In contrast to such research, our study found that TMT faultline presence strengthens the TMT effect on Chinese firms' degree of FDI ambidexterity. This finding can be attributed to the Chinese context, as we argued in hypothesis development. Strong and long-lasting interpersonal relationships, known as guanxi (Yang, 1994), are particularly valued in Chinese culture. In a team environment, members tend to focus on collective harmony, emphasize similarity and deemphasize difference, and avoid aggressive ways of working with each other (Tjosvold, Poon, \& Yu, 2005). For Chinese firms, faultline presence can play a positive role in breaking the cultural confinement of TMT and allow top managers to engage in genuine task-related 
debate. In an environment where the default cultural value hinders diversity benefits, inducing team faultline presence can be an effective way to activate constructive interactions between the members, which then enhances a TMT's managerial efficacy in coordinating ambidextrous FDI strategy.

Our finding on the moderating effect of formal institutions also supports our hypothesis. Specifically, when the home institutional environment is underdeveloped, this limits Chinese firms' external knowledge- and information- seeking efforts because of failed market signals and insufficient consultancy intermediaries. Such an environment will motivate Chinese firms to rely more on their TMTs' knowledge and skills when pursuing important strategies (such as ambidextrous FDI). These findings highlight the importance of contextual factors in TMT research (Cannella et al., 2008). We demonstrate that the joint consideration of informal and formal institutional contexts is important for understanding the role of the TMT on Chinese firms' FDI strategy.

A closer look at our moderating hypotheses results suggests that the marginal effect of TMT functional diversity on FDI ambidexterity is only significant when TMT faultline presence is sufficiently strong (above the sample mean: see Figure 1). This result suggests that the socialization context is critically important for TMTs to make material the benefits of the complementary knowledge of the members. In the context of this study, because of the overall cultural constraints on individuals from challenging each other, the socialization context within the TMT plays a significant role in promoting the salience of the role of strategic decision makers in order to overcome the tendency to pursue group harmony and consensus. Future TMT research should further investigate the micro-foundations of TMT effects from a social identity perspective, where the socialization contexts both outside and within the TMT may alter the role orientation of TMT members. Furthermore, results on our second moderating hypothesis suggest that the marginal effect of TMT functional diversity 
on FDI ambidexterity is only significant when the formal market institution is underdeveloped (below the sample mean: see Figure 2). The implication is that diversified managerial knowledge, as opposed to specialization of managerial expertise, is value-adding when access to complementary knowledge through external market is unfeasible or costly. This insight contributes to the knowledge-based view of the firm by highlighting the institutional determination of the boundary of the firm, or indeed the optimal knowledge composition of the firm. What remains unclear, from our findings, is that when and under what conditions will specialization of managerial expertise start to become more efficient than diversification of managerial knowledge for complex strategic decision-making.

\section{Theoretical Implications}

Chinese firms' FDI strategy has been characterized as unconventional compared to that of developed multinational corporations (Cui et al., 2014; Ramamurti, 2012). Under their unique competitive and institutional environments, more and more Chinese firms prefer to adopt an ambidextrous FDI strategy with exploration and exploitation simultaneously, but they often face a difficult task in pursuing their FDI strategy when they need to manage various, or even seemingly contrasting, resource and structure requirements for ambidextrous FDI (Luo \& Rui, 2009). As such, we argue that international business research can draw insights from the TMT research agenda, in particular the notion of creative diversity in organizations, so as to gain new perspectives for understanding the ambidextrous internationalization strategy of Chinese firms and of emerging economy firms more generally. Through integrating the upper-echelon perspective and the new institutional economics, this study highlights the conditional positive effect of TMT's creative diversity within various institutional contingencies. Beyond the knowledge and experience of TMT members, our findings suggest that the composition of the TMT, especially the level of expertise diversity enabled by that 
composition, can play an important role in supporting ambidextrous FDI strategy of Chinese firms, but its influence is contingent on the informal and formal institutional environments. In general, while international business literature has a stronger focus on the institutional context of strategic decision-making (Peng et al., 2008), a TMT perspective can inform the micro-foundations of international business strategy. This study demonstrates that integrating these two research streams can potentially enhance our understanding of emerging international business phenomena, which is a main benefit of an interdisciplinary approach to scientific inquiry (Cropanzano \& Mitchell, 2005; Deng, 2013).

In addition, TMT scholars argue that existing research omits important contextual factors (such as institutions) (Cannella et al., 2008), and decontextualization of TMT research runs the risk of ignoring the effects of embeddedness of TMTs in an institutional context (Carpenter, 2002). Our study demonstrates that it is pivotal to consider relevant institutional environments in order to understand when and under what conditions TMTs have a strong motivation to utilize their diversified knowledge for strategic decision-making. Given that TMTs' decision-making and firm actions are constrained by the environments in which firms operate (Nielsen \& Nielsen, 2013), it is crucial to identify relevant institutional factors that may influence the TMT diversity-FDI strategy relationship. Through investigating moderating effects of informal and formal institutional environments, our study helps TMT scholars to understand various institutional contingencies in TMT's strategy-related decisionmaking process.

\section{Limitations and Future Research Directions}

We acknowledge the limitations of this study that point to several future research directions. First, the empirical analysis was carried out in a single country context. Although this design can effectively control for potential country-level effects in the analysis, caution must be 
exercised when generalizing its findings. Future research would be well served by exploring whether similar results emerge in other country contexts and by performing comparative studies on firms from different home countries. Second, the moderating role of TMT faultline presence on the main effect seems contingent on TMTs' social cultural values. Future research can explore the effects of multiple cultural dimensions on the role of TMT faultline presence in the TMT functional diversity and degree of FDI ambidexterity relationship. Lastly, a TMT's decision-making process may be influenced by the CEO's leadership style. Certain leadership style may help promote the TMT diversity effect on the firm's strategy. Apart from faultline presence, future research can investigate CEO leadership as a potential informal institution influencing the TMT's role in strategizing.

\section{Acknowledgements}

This research is supported by funding from the Australian Research Council (DE130100860) and National Natural Science Foundation of China (71472038). We also thank the editor-inchief Professor Arie Lewin, the senior editor Professor Xiaohui Liu, two anonymous reviewers, and participants at the 2014 Academy of International Business conference for their constructive comments. 


\section{REFERENCES}

Amason, A. C. 1996. Distinguishing the effects of functional and dysfunctional conflict on strategic decision making: resolving a paradox for top management teams. Academy of Management Journal, 39(1): 123-148.

Ancona, D. G., \& Caldwell, D. C. 1992. Demography and design: Predictors of new product team performance. Organization Science, 3(3): 321-341.

Bantel, K. A., \& Jackson, S. E. 1989. Top management and innovations in banking: Does the composition of the top team make a difference? Strategic Management Journal, Summer Special Issue 10(S1): 107-124.

Barkema, H., \& Drogendijk, R. 2007. Internationalizing in small, incremental or large steps? Journal of International Business Studies, 38: 1132-1148

Barkema, H., \& Shvyrkov, O. 2007. Does top management team diversity promote or hamper foreign expansion? Strategic Management Journal, 28(7): 663-680.

Besharov, M. L., \& Smith, W. K. 2014. Multiple institutional logics in organizations: Explaining their varied nature and implication. Academy of Management Review, 39(3): $364-381$.

Bezrukova, K., Jehn, K. A., Zanutto, E. L., \& Thatcher, S. M. B. 2009. Do workgroup faultlines help or hurt? A moderated model of faultlines, team identification, and group performance. Organization Science, 20(1): 35-50.

Blau, P. M. 1977. Inequality and Heterogeneity. New York: Free Press.

Boeker, W., \& Wiltbank, R. 2005. New venture evolution and managerial capabilities. Organization Science, 16(2): 123-133.

Boone, C., \& Hendriks, W. 2009. Top management team diversity and firm performance: Moderators of functional-background and locus-of-control diversity. Management Science, 55(2): 165-180. 
Brambor, T., Clark, W. R., \& Golder, M. 2006. Understanding interaction models: Improving empirical analyses. Political analysis, 14(1): 63-82.

Cannella, A. A., Jr., Park, J., \& Lee, H. 2008. Top management team functional background diversity and firm performance: Examining the roles of team member collocation and environmental uncertainty. Academy of Management Journal, 51(4): 768-784.

Cao, Q., Gedajlovic, E., \& Zhang, H. 2009. Unpacking organizational ambidexterity: Dimensions, contingencies, and synergistic effects. Organization Science, 20: 781-796.

Cao, Q., Simsek, Z., \& Zhang, H. 2009. Modelling the joint impact of the CEO and the TMT on organizational ambidexterity. Journal of Management Studies, 47(7): 1272-1296.

Carpenter, M. A. 2002. The implications of strategy and social context for the relationship between top management team heterogeneity and firm performance. Strategic Management Journal, 23(3): 275-284.

Carpenter, M. A., \& Fredrickson, J. W. 2001. Top management teams, global strategic posture, and the moderating role of uncertainty. Academy of Management Journal, 44(3): 533-545.

Carpenter, M. A., Geletkanycz, M. A., \& Sanders, W. G. 2004. Upper echelons research revisited: Antecedents, elements, and consequences of top management team composition. Journal of Management, 30(6): 749-778.

Carpenter, M. A., \& Sanders, W. G. 2004. The effects of top management team pay and firm internationalization on MNC performance. Journal of Management, 30(4): 509-528.

Caves, R. E. 1971. International corporations: the industrial economics of foreign investment. Economica, 38(149): 1-27.

Chizema, A., Liu, X., Lu, J., \& Gao, L. 2015. Politically connected boards and top executive pay in Chinese listed firms. Strategic Management Journal, 36(6): 890-906.

Claessens, S., Djankov, S., Fan, J. R. H., \& Lang, L. H. P. 2002. Disentangling the incentive and entrenchment effects of large shareholdings. Journal of Finance, 57(6): 2741-2771. 
Cropanzano, R., \& Mitchell, M. S. 2005. Social exchange theory: An interdisciplinary review. Journal of Management, 31: 874-900.

Cui, L. 2016. The primacy of institutional explanation of Chinese outward FDI: Is it understated or overstated? Management and Organization Review, 12(3): 457-467.

Cui, L., \& Jiang, F. M. 2012. State ownership effect on firms' FDI ownership decisions under institutional pressure: A study of Chinese outward-investing firms. Journal of International Business Studies, 43(3): 264-284.

Cui, L., Li, Y., Meyer, K., \& Li, Z. 2015. Leadership experience meets ownership structure: Returnee managers and internationalization of emerging economy firms. Management International Review, 55(3): 355-387.

Cui, L., Meyer, K. E., \& Hu, H. W. 2014. What drives firms' intent to seek strategic assets by foreign direct investment? A study of emerging economy firms. Journal of World Business, 49(4): 488-501.

Dau, L. A. 2016. Biculturalism, team performance, and cultural-faultline bridges. Journal of International Management, 22(1): 48-62.

D’Aveni, R., \& Kesner, I. 1993. Top managerial prestige, power and tender offer response: A study of elite social networks and target firm cooperation during takeovers. Organization Science, 4(2): 123-151.

Deng, P. 2013. Chinese outward direct investment research: Theoretical integration and recommendations. Management and Organization Review, 9(3): 513-39.

Doz, Y. L., \& Kosonen, M. 2007. The new deal at the top. Harvard Business Review, 85(6): 98-104.

Dunning, J. H. 1988. The electric paradigm of international production: A restatement and some possible extensions. Journal of International Business Studies, 19(1): 1-31. 
Dunning, J. H., \& Lundan, S. M. 2008. Multinational enterprises and the global economy. Cambridge, MA: Edward Elgar Publishing.

Eisenhardt, K. M., \& Bourgeois, L. J. 1988. Politics of strategic decision making in highvelocity environments: Toward a midrange theory. Academy of Management Journal, 31(4): 737-770.

Ellemers, N., \& Rink, F. 2005. Identity in work groups: The beneficial and detrimental consequences of multiple identities and group norms for collaboration and group performance. Advances in Group Processes, 22: 1-41.

Estrin, S., Poukiakova, S., \& Shapiro, D. 2009. The performance of business groups in Russia. Journal of Management Studies, 46(3): 393-420.

Fan, G., Wang, X. L., \& Zhu, H. P. 2007. Marketization index in China: The regional process report of 2006. Beijing: Economic Science Press (in Chinese).

Fernhaber, S., \& Patel, P. 2012. How do young firms manage product portfolio complexity? The role of absorptive capacity and ambidexterity. Strategic Management Journal, 33(13): $1516-1539$.

Finkelstein, S., \& Hambrick, D. C. 1990. Top-management-team tenure and organizational outcomes: the moderating role of managerial discretion. Administrative Science Quarterly, 35(3): 484-503.

Floyd, S., \& Lane, P. 2000. Strategizing throughout the organization: Managing role conflict in strategic renewal. Academy of Management Review, 25(1): 154-77.

Forbes, D. P., \& Milliken, F. J. 1999. Cognition and corporate governance: Understanding boards of directors as strategic decision-making groups. Academy of Management Review, 24(3): 489-505.

Gibson, C. B., \& Birkinshaw, J. 2004. The antecedents, consequences, and mediating role of organizational ambidexterity. Academy of management Journal, 47(2): 209-226. 
Granger, C. W. J. 1969. Investigating causal relations by econometric models and crossspectral methods. Econometrica, 37(3): 424-438.

Greve, H. R. 2003. A behavioral theory of R\&D expenditures and innovations: Evidence from shipbuilding. Academy of Management Journal, 46(6): 685-702.

Haleblian, J., \& Finkelstein, S. 1993. Top management team size, CEO dominance, and firm performance: the moderating roles of environmental turbulence and discretion. Academy of Management Journal, 36(4): 844-863.

Hambrick, D. C., Cho, S. T., \& Chen, M. J. 1996. The influence of TMT heterogeneity on firm's competitive moves. Administrative Science Quarterly, 41: 659-684.

Hambrick, D. C., \& Mason, P. A. 1984. Upper echelons: The organization as a reflection of its top managers. Academy of Management Journal, 9(2): 193-206.

Harzing, A. W., Brown, M., Koster, K., \& Zhao, S. M. 2012. Response style differences in cross-national research dispositional and situational determinants. Management International Review, 52(3): 341-363.

He, Z. L., \& Wong, P. K. 2004. Exploration vs. exploitation: An empirical test of the ambidexterity hypothesis. Organization science, 15(4): 481-494.

Hitt, M., Hoskisson, R., \& Kim, H. 1997. International diversification: Effects on innovation and firm performance in product-diversified firms. Academy of Management Journal, 40(4): 767-798.

Hsu, C. W., Lien, Y. C., \& Chen, H. 2013. International ambidexterity and firm performance in small emerging economies. Journal of World Business, 48(1): 58-67.

Hutzschenreuter, T., \& Horstkotte, J. 2013. Performance effects of top management team demographic faultlines in the process of product diversification. Strategic Management Journal, 34(6): 704-726. 
Hymer, S. 1976. The international operations of national firms: A study of direct investment. MIT Press: Cambridge, MA.

Ireland, R. D., \& Webb, J. W. 2007. Strategic entrepreneurship: Creating competitive advantage through streams of innovation. Business Horizons, 50: 49-59.

Jackson, S. E. 1992. Consequences of group composition for the interpersonal dynamics of strategic issue processing. In P. Shrivastava, A. Huff, \& J. Dutton (Eds.), Advances in Strategic Management (Vol. 8): 345-382. JAI Press: Greenwich, CT.

Jehn, K. A. 1995. A multimethod examination of the benefits and detriments of intragroup conflict. Administrative Science Quarterly, 40(2): 256-282.

Jehn, K. A. 1997. A qualitative analysis of conflict types and dimensions in organizational groups. Administrative Science Quarterly, 42(3): 530-557.

Jehn, K. A., Northcraft, G. B., \& Neale, M. A. 1999. Why differences make difference: A field study of diversity, conflict, and performance in workgroups. Administrative Science Quarterly, 44(4): 741-763.

Karasek, R. A. 1979. Job demands, job decision latitude, and mental strain: Implications for job redesign. Administrative Science Quarterly, 24(2): 285-309.

Katila, R., \& Ahuja, G. 2002. Something old, something new: A longitudinal study of search behavior and new product introduction. Academy of Management Journal, 45(6): 11831194.

Keats, B. W., \& Hitt, M. A. 1988. A causal model of linkages among environmental dimensions, macro organizational characteristics, and performance. Academy of Management Journal, 31(3): 570-598.

Kim, M., Mahoney, J. T., \& Tan, D. 2015. Re-conceptualizing exploitative and explorative FDI: A balancing-process approach to firm internationalization. European Journal of International Management, 9(5): 537-565. 
Kim, T., Shin, D., Oh, H., \& Jeong, Y. 2007. Inside the iron cage: Organizational political dynamics and institutional changes in presidential selection systems in Korean universities, 1985-2002. Administrative Science Quarterly, 52(2): 286-323.

Knudsen, T., \& Madsen, T. K. 2002. Export strategy: A challenge to traditional internationalization theory. Scandinavian Journal of Management, 18(4): 475-502.

Lee, H. U., \& Park, J. H. 2006. Top team diversity, internationalization and the mediating effect of international alliances. British Journal of Management, 17(3): 195-213.

Levinthal, D. A., \& March, J. G. 1993. The myopia of learning. Strategic Management Journal, 14(Winter): 95-112.

Lovelace, K., Shapiro, D. L., \& Weingart, L. R. 2001. Maximizing cross-functional new product teams' innovativeness and constraint adherence: A conflict communications perspective. Academy of Management Journal, 44(4): 779-793.

Lu, J. W., \& Beamish, P. W. 2004. International diversification and firm performance: The Scurve hypothesis. Academy of Management Journal, 47(4): 598-609.

Lu, J., Liu, X., \& Wang, H. 2011. Motives for outward FDI of Chinese private firms: Firm resources, industry dynamics, and government policies. Management and Organization Review, 7(2): 223-248.

Luo, X., Wang, H., Raithel, S., \& Zheng, Q. 2015. Corporate social performance, analyst stock recommendations, and firm future returns. Strategic Management Journal, 36: 123-136.

Luo, Y. 2002. Capability exploitation and building in a foreign market: Implications for multinational enterprises. Organization Science, 13: 48-63.

Luo, Y., \& Rui, H. 2009. An ambidexterity perspective toward multinational enterprises from emerging economies. Academy of Management Perspective, 23: 49-70.

Lyles, M., Li, D., \& Yan, H. 2014. Chinese outward FDI performance: The role of learning. Management and Organization Review, 10: 411-437. 
March, J. G. 1991. Exploration and exploitation in organizational learning. Organization Science, 2: 71-87.

Markides, C. 2013. Business model innovation: What can the ambidexterity literature teach us? Academy of Management Perspectives, 27: 313-323.

Meyer, K. E. 2015. Context in Management Research in Emerging Economies. Management and Organization Review, 11: 369-377.

Meyer, K.E., \& Xin, K.R. 2017. Managing Talent in Emerging Economy Multinationals: Integrating Strategic Management and Human Resource Management, International Journal of Human Resource Management, forthcoming.

Miller, C. C., Burke, L. M., Glick, W. H. 1998. Cognitive diversity among upper-echelon executives: implications for strategic decision process. Strategic Management Journal, 19: $39-58$.

Minkov, M., \& Hofstede, G. 2012. Is national culture a meaningful concept? Cultural values delineate homogeneous national clusters of in-country regions. Cross-Cultural Research, 46: $133-159$.

Morck, R., Yeung, B., \& Zhao, M. 2008. Perspectives on China's outward foreign direct investment. Journal of International Business Studies, 39: 337-350.

Nadkarni, S., \& Perez, P. 2007. Prior conditions and degree of internationalization: The mediating role of domestic mindsets. Journal of International Business Studies, 38: 160176.

Nielsen, B., \& Nielsen, S. 2013. Top management team nationality diversity and firm performance: A multilevel study. Strategic Management Journal, 34: 373-382.

North, D. C. 1990. Institutions, institutional change and economic performance. Cambridge University Press. 
Pananond, P. (2015). Motives for foreign direct investment: a view from emerging market multinationals. The Multinational Business Review, 23(1): 77-86.

Pelled, L. H., Eisenhardt, K., \& Xin, K. R. 1999. Exploring the black box: An analysis of work group diversity, conflict and performance. Administrative Science Quarterly, 44: 1-28.

Peng, M. W. 2012. The global strategy of emerging multinationals from China. Global Strategy Journal, 2: 97-107.

Peng, M. W., Wang, D. Y., \& Jiang, Y. 2008. An institution-based view of international business strategy: A focus on emerging economies. Journal of International Business Studies, 39: 920-936.

Porter, M. E. 1996. What is strategy? Harvard Business Review, 74(November-December), $61-78$.

Posthuma, R. A., \& Campion, M. A. 2009. Age stereotypes in the workplace: Common stereotypes, moderators, and future research directions. Journal of Management, 35: 158188.

Qian, C., Cao, Q., \& Takeuchi, R. 2013. Top management team functional diversity and organizational innovation in China: The moderating effects of environment. Strategic Management Journal, 34: 110-120.

Raisch, S., \& Birkinshaw, J. 2008. Organizational ambidexterity: Antecedents, outcomes, and moderators. Journal of Management, 34: 375-409.

Ramamurti, R. 2012. What is really different about emerging market multinationals? Global Strategy Journal, 2: 41-47.

Rugman, A. M. 1980. Internalization as a general theory of foreign direct investment. Review of World Economics, 116(2): 365-379. 
Rugman, A. M., \& Verbeke, A. 2009. Location, competitiveness and the multinational enterprise. In A. M. Rugman (Ed.), The Oxford Handbook of International Business (2nd ed., pp. 146-180). Oxford: Oxford University Press.

Shi, W., Sun, S., \& Peng, M. 2012. Sub-national institutional contingencies, network positions, and IJV partner selection. Journal of Management Studies, 49: 1221-1245.

Smith, W. K., \& Tushman, M. 2005. Managing strategic paradox: A model of top management teams managing exploration and exploitation simultaneously. Organization Science, 16: $522-36$.

Teece, D. J. 2010. Business models, business strategy and innovation. Long Range Planning, 43: 172-194.

Thatcher, S., Jehn, K., \& Zanutto, E. 2003. Cracks in diversity research: The effects of diversity faultlines on conflict and performance. Group Decision and Negotiation, 12: 217-241.

Tjosvold, D., Law, K. S., \& Sun, H. 2006. Effectiveness of Chinese teams: The role of conflict types and conflict management approaches. Management and Organization Review, 2: $231-252$.

Tjosvold, D., Poon, M., \&Yu, Z. 2005. Team effectiveness in China: Cooperative conflict for relationship building. Human Relations, 58: 341-367.

Wang, C. L., \& Ahmed, P. K. 2007. Dynamic capabilities: A review and research agenda. International Journal of Management Reviews, 9: 31-51.

Wang, C., Hong, J., Kafouros, M., \& Wright, M. 2012. Exploring the role of government involvement in outward FDI from emerging economies. Journal of International Business Studies, 43: 655-676.

Wiersema, M. F., \& Bantel, K. 1992. Top management team demography and corporate strategic change. Academy of Management Journal, 35: 91-121. 
Yang, H., Lin, Z., \& Lin, Y. 2010. A multilevel framework of firm boundaries: firm characteristics, dyadic differences, and network attributes. Strategic Management Journal, 31: $237-261$.

Yang, M. M. 1994. Gifts, Favors and Banquets: The Arts of Social Relationships in China. Cornell University Press: Ithaca, NY.

Zaheer, S. 1995. Overcoming the liability of foreignness. Academy of Management Journal, 38: $341-363$.

Zanutto, E., Bezrukova, K., \& Jehn, K. 2011. Revisiting faultline conceptualization: Measuring faultline strength and distance. Quality \& Quantity, 45: 701-714.

Zou, H., \& Adams, M. B. 2008. Corporate ownership, equity risk and returns in the People's Republic of China. Journal of International Business Studies, 39: 1149-1168. 
Table 1. Descriptive statistics and correlations

\begin{tabular}{|c|c|c|c|c|c|c|c|c|c|c|c|c|c|c|c|}
\hline Variables & 1 & 2 & 3 & 4 & 5 & 6 & 7 & 8 & 9 & 10 & 11 & 12 & 13 & 14 & 15 \\
\hline 1 TMT Size & 1.00 & & & & & & & & & & & & & & \\
\hline 2 Firm Size & 0.01 & 1.00 & & & & & & & & & & & & & \\
\hline 3 Past Performance & 0.04 & 0.12 & 1.00 & & & & & & & & & & & & \\
\hline 4 Group Affiliation & 0.05 & -0.03 & -0.09 & 1.00 & & & & & & & & & & & \\
\hline 5 State-Owned Enterprise & 0.10 & -0.02 & 0.06 & 0.29 & 1.00 & & & & & & & & & & \\
\hline 6 Legal-Person Ownership & -0.01 & -0.07 & 0.04 & 0.31 & 0.17 & 1.00 & & & & & & & & & \\
\hline $\begin{array}{l}7 \text { Ultimate Shareholder Excess } \\
\text { Control }\end{array}$ & 0.00 & 0.06 & 0.03 & 0.19 & -0.23 & 0.29 & 1.00 & & & & & & & & \\
\hline 8 Environmental Munificence & 0.11 & 0.02 & -0.03 & 0.04 & 0.10 & -0.08 & -0.10 & 1.00 & & & & & & & \\
\hline 9 Environmental Dynamism & 0.00 & 0.03 & 0.02 & 0.01 & 0.10 & 0.10 & 0.11 & -0.21 & 1.00 & & & & & & \\
\hline $\begin{array}{l}10 \text { Degree of } \\
\text { Internationalization }\end{array}$ & 0.07 & 0.09 & -0.10 & -0.02 & -0.18 & -0.13 & 0.15 & -0.05 & -0.05 & 1.00 & & & & & \\
\hline 11 Inverse Mills Ratio & -0.29 & 0.15 & 0.25 & -0.13 & 0.42 & 0.18 & -0.35 & -0.19 & -0.26 & -0.44 & 1.00 & & & & \\
\hline $\begin{array}{l}12 \text { Degree of FDI } \\
\text { Ambidexterity }\end{array}$ & 0.21 & 0.06 & -0.05 & -0.03 & -0.03 & -0.03 & -0.11 & 0.00 & -0.03 & 0.05 & -0.04 & 1.00 & & & \\
\hline 13 TMT Functional Diversity & 0.17 & -0.05 & -0.01 & 0.01 & -0.05 & 0.02 & 0.10 & 0.01 & 0.00 & 0.00 & -0.13 & 0.02 & 1.00 & & \\
\hline 14 TMT Faultline Presence & -0.20 & 0.02 & -0.02 & 0.01 & 0.06 & -0.01 & -0.08 & -0.03 & -0.01 & 0.01 & 0.08 & -0.11 & -0.01 & 1.00 & \\
\hline $\begin{array}{l}15 \text { Formal Institutional } \\
\text { Development }\end{array}$ & -0.09 & -0.03 & -0.01 & 0.02 & -0.07 & -0.07 & -0.05 & -0.06 & -0.13 & 0.13 & -0.03 & -0.07 & -0.01 & 0.04 & 1.00 \\
\hline Mean & 6.06 & 12.63 & 5.39 & 0.51 & 0.61 & 41.77 & 6.99 & 1.26 & 1.03 & 0.24 & 5.44 & 0.20 & 0.53 & 0.59 & 9.28 \\
\hline Standard Deviation & 2.61 & 1.38 & 15.21 & 0.50 & 0.49 & 18.94 & 8.82 & 0.06 & 0.04 & 0.26 & 0.88 & 0.30 & 0.14 & 0.23 & 1.80 \\
\hline
\end{tabular}


Table 2. Results of two-stage regression models

\begin{tabular}{lccccc}
\hline & The First-Stage & \multicolumn{3}{c}{ The Second-Stage } \\
\hline & Model 1 & Model 2 & Model 3 & Model 4 & Model 5 \\
\hline Intercept & -2.56 & -0.08 & -0.08 & -0.07 & -0.07 \\
& $(5.92)$ & $(0.12)$ & $(0.13)$ & $(0.13)$ & $(0.13)$ \\
Independent Variable & & & & & \\
TMT Functional Diversity (H1) & & & $0.09 \dagger$ & 0.08 & $0.14^{*}$ \\
Moderators & & $(0.05)$ & $(0.05)$ & $(0.06)$ \\
TMT Faultline Presence & & & & \\
& & & 0.00 & 0.01 & 0.00 \\
Formal Institutional Development & & & $-0.05)$ & $(0.05)$ & $(0.05)$ \\
& & & $(0.08)$ & -0.03 & -0.02 \\
& & & & $(0.08)$ & $(0.08)$
\end{tabular}

\section{Two-Way Interactions}

TMT Functional Diversity $\times$ TMT

Faultline Presence (H2)

TMT Functional Diversity $\times$ Formal

$-0.11^{*}$

Institutional Development (H3)

\section{Controls}

TMT Size

\begin{tabular}{ccccc}
0.08 & $0.16^{* *}$ & $0.14^{*}$ & $0.16^{* *}$ & $0.14 *$ \\
$(0.08)$ & $(0.06)$ & $(0.06)$ & $(0.06)$ & $(0.06)$ \\
$-0.17^{* *}$ & 0.01 & 0.01 & 0.01 & 0.02 \\
$(0.07)$ & $(0.03)$ & $(0.03)$ & $(0.03)$ & $(0.03)$ \\
$-0.01 \dagger$ & 0.01 & 0.01 & 0.00 & 0.01 \\
$(0.01)$ & $(0.03)$ & $(0.03)$ & $(0.03)$ & $(0.03)$ \\
0.39 & 0.07 & 0.08 & 0.09 & 0.08 \\
$(0.33)$ & $(0.18)$ & $(0.18)$ & $(0.18)$ & $(0.18)$ \\
$-0.68^{*}$ & -0.03 & -0.03 & -0.04 & -0.03 \\
$(0.31)$ & $(0.08)$ & $(0.08)$ & $(0.08)$ & $(0.08)$ \\
-0.01 & 0.01 & 0.01 & -0.01 & 0.01 \\
$(0.01)$ & $(0.06)$ & $(0.06)$ & $(0.06)$ & $(0.06)$ \\
$0.02 \dagger$ & -0.10 & $-0.11 \dagger$ & -0.09 & $-0.11 \dagger$ \\
$(0.01)$ & $(0.07)$ & $(0.07)$ & $(0.07)$ & $(0.07)$ \\
$3.84 *$ & -0.06 & -0.05 & -0.05 & -0.05 \\
$(1.90)$ & $(0.05)$ & $(0.05)$ & $(0.05)$ & $(0.05)$ \\
$6.79 * *$ & 0.02 & 0.03 & 0.02 & 0.03 \\
$(2.64)$ & $(0.06)$ & $(0.06)$ & $(0.06)$ & $(0.06)$ \\
$1.14 \dagger$ & 0.00 & 0.00 & 0.00 & 0.00 \\
$(0.59)$ & $(0.05)$ & $(0.05)$ & $(0.05)$ & $(0.05)$ \\
1.56 & & & & \\
$(1.13)$ & & & & \\
$-0.14 \dagger$ & & & & \\
$(0.08)$ & & & & \\
$-1.18^{* * *}$ & & & & \\
$(0.36)$ & & & & \\
& -0.06 & -0.06 & -0.05 & -0.06 \\
& $(0.06)$ & $(0.06)$ & $(0.06)$ & $(0.06)$ \\
\hline 548.22 & 0.06 & 0.07 & 0.08 & 0.09 \\
$67.49 * * *$ & $18.41 \dagger$ & $21.48 \dagger$ & $27.64 *$ & $25.83 *$ \\
193 & 374 & 374 & 374 & 374 \\
\hline $\mathrm{p}<0.10, * \mathrm{p}<0.05, * * \mathrm{p}<0.01, * * * \mathrm{p}<0.001(\mathrm{two}-\mathrm{tailed})$. \\
& & & &
\end{tabular}

Firm Size

Past Performance

$+2$

Group Affiliation

State-Owned Enterprise

Legal-Person Ownership

Ultimate Shareholder Excess Control

Environmental Munificence

Environmental Dynamism

Degree of Internationalization

Industry Rate of Globalization

Change

Key FDI Regulations in China

Foreign Exchange Rate

Inverse Mills Ratio

Log- likelihood / R-Square

Wald Chi-square 193

Standard errors are reported in parentheses. $\dagger \mathrm{p}<0.10, * \mathrm{p}<0.05, * * \mathrm{p}<0.01, * * * \mathrm{p}<0.001$ (two-tailed). 
Table 3. Results of Results of robustness tests

\begin{tabular}{|c|c|c|c|c|c|}
\hline \multirow[t]{2}{*}{ Dependent Variable } & \multirow{2}{*}{$\begin{array}{c}\text { FDI Decision } \\
\text { Dummy } \\
\text { (The First- } \\
\text { Stage) } \\
\text { Model } 6 \\
\end{array}$} & \multicolumn{4}{|c|}{$\begin{array}{l}\text { Ambidextrous FDI Dummy } \\
\text { (The Second-Stage) }\end{array}$} \\
\hline & & Model 7 & Model 8 & Model 9 & Model 10 \\
\hline Intercept & $\begin{array}{c}-9.88 \\
(15.34)\end{array}$ & $\begin{array}{c}70.30^{*} \\
(29.40)\end{array}$ & $\begin{array}{c}71.27^{*} \\
(32.40)\end{array}$ & $\begin{array}{c}62.37^{*} \\
(31.31)\end{array}$ & $\begin{array}{c}68.11^{*} \\
(31.88)\end{array}$ \\
\hline \multicolumn{6}{|l|}{ Independent Variable } \\
\hline TMT Functional Diversity & & $\begin{array}{r}5.65^{*} \\
(2.18)\end{array}$ & $\begin{array}{l}6.66^{* *} \\
(2.35)\end{array}$ & $\begin{array}{l}5.88^{* *} \\
(2.18)\end{array}$ & $\begin{array}{l}6.26^{*} \\
(2.46)\end{array}$ \\
\hline \multicolumn{6}{|l|}{ Moderators } \\
\hline TMT Faultline Distance & & $\begin{array}{l}6.41 \\
(4.31) \\
-1.52 \\
(2.12)\end{array}$ & $\begin{array}{l}5.71 \\
(5.03) \\
-1.40 \\
(2.35)\end{array}$ & $\begin{array}{l}6.82 \\
(4.39) \\
-1.55 \\
(2.30)\end{array}$ & $\begin{array}{l}7.50 \\
(5.30) \\
-2.89 \\
(2.27)\end{array}$ \\
\hline $\begin{array}{l}\text { Development of Institutional } \\
\text { Intermediaries }\end{array}$ & & $\begin{array}{l}-0.56 \\
(0.35)\end{array}$ & $\begin{array}{l}-0.61 \\
(0.41)\end{array}$ & $\begin{array}{l}-0.54 \\
(0.34)\end{array}$ & $\begin{array}{l}-0.80 \dagger \\
(0.42)\end{array}$ \\
\hline \multicolumn{6}{|l|}{ Two-Way Interactions } \\
\hline $\begin{array}{l}\text { TMT Functional Diversity } \times \\
\text { TMT Faultline Strength }(\mathbf{H 1})\end{array}$ & & & $\begin{array}{c}0.78 \\
(0.59)\end{array}$ & & \\
\hline $\begin{array}{l}\text { TMT Functional Diversity } \times \\
\text { TMT Faultline Distance }(\mathbf{H 1})\end{array}$ & & & & $\begin{array}{c}0.93 \dagger \\
(0.55)\end{array}$ & \\
\hline $\begin{array}{l}\text { TMT Functional Diversity } \\
\times \text { Development of Institutional } \\
\text { Intermediaries }(\mathbf{H 2})\end{array}$ & & & & & $\begin{array}{l}-2.67 * * \\
(0.88)\end{array}$ \\
\hline \multicolumn{6}{|l|}{ Controls } \\
\hline TMT Size & $\begin{array}{c}0.08 \\
(0.08)\end{array}$ & $\begin{array}{c}0.44 \\
(0.33)\end{array}$ & $\begin{array}{c}0.45 \\
(0.35)\end{array}$ & $\begin{array}{c}0.46 \\
(0.33)\end{array}$ & $\begin{array}{c}0.49 \\
(0.37)\end{array}$ \\
\hline Firm Size & $\begin{array}{l}-0.17 * * \\
(0.06)\end{array}$ & $\begin{array}{c}0.43 \\
(0.35)\end{array}$ & $\begin{array}{c}0.41 \\
(0.38)\end{array}$ & $\begin{array}{c}0.38 \\
(0.35)\end{array}$ & $\begin{array}{c}0.48 \\
(0.35)\end{array}$ \\
\hline Past Performance & $\begin{array}{l}-0.01 \\
(0.01)\end{array}$ & $\begin{array}{c}0.02 \\
(0.04)\end{array}$ & $\begin{array}{c}0.02 \\
(0.05)\end{array}$ & $\begin{array}{c}0.02 \\
(0.04)\end{array}$ & $\begin{array}{c}0.02 \\
(0.04)\end{array}$ \\
\hline Group Affiliation & $\begin{array}{c}0.39 \\
(0.32)\end{array}$ & $\begin{array}{c}0.08 \\
(1.63)\end{array}$ & $\begin{array}{c}0.96 \\
(1.66)\end{array}$ & $\begin{array}{c}0.26 \\
(1.61)\end{array}$ & $\begin{array}{c}0.27 \\
(1.69)\end{array}$ \\
\hline State-Owned Enterprise & $\begin{array}{l}-0.61^{*} \\
(0.30)\end{array}$ & $\begin{array}{c}1.33 \\
(1.55)\end{array}$ & $\begin{array}{c}1.26 \\
(1.72)\end{array}$ & $\begin{array}{c}1.04 \\
(1.58)\end{array}$ & $\begin{array}{c}1.39 \\
(1.66)\end{array}$ \\
\hline Legal-Person Ownership & $\begin{array}{l}-0.01 \\
(0.01)\end{array}$ & $\begin{array}{r}0.06 \dagger \\
(0.04)\end{array}$ & $\begin{array}{c}0.06 \\
(0.04)\end{array}$ & $\begin{array}{c}0.04 \\
(0.04)\end{array}$ & $\begin{array}{c}0.07 \dagger \\
(0.04)\end{array}$ \\
\hline $\begin{array}{l}\text { Ultimate Shareholder Excess } \\
\text { Control }\end{array}$ & $\begin{array}{c}0.03 \dagger \\
(0.01)\end{array}$ & $\begin{array}{l}-0.01 \\
(0.08)\end{array}$ & $\begin{array}{l}-0.01 \\
(0.09)\end{array}$ & $\begin{array}{c}0.01 \\
(0.08)\end{array}$ & -0.03 \\
\hline Environmental Munificence & $\begin{array}{l}2.25 \\
(1.82)\end{array}$ & $\begin{array}{r}-25.22 * * \\
(8.90)\end{array}$ & $\begin{array}{l}-25.63^{*} \\
(10.31)\end{array}$ & $\begin{array}{c}-24.68 * * \\
(9.40)\end{array}$ & $\begin{array}{l}-25.78^{* *} \\
(9.36)\end{array}$ \\
\hline
\end{tabular}




\begin{tabular}{|c|c|c|c|c|c|}
\hline Environmental Dynamism & $\begin{array}{l}10.41 \\
(8.51)\end{array}$ & $\begin{array}{l}-51.28 * \\
(22.37)\end{array}$ & $\begin{array}{l}-52.64 * \\
(24.42)\end{array}$ & $\begin{array}{l}-45.13 \dagger \\
(23.57)\end{array}$ & $\begin{array}{l}-48.72 * \\
(24.74)\end{array}$ \\
\hline Degree of Internationalization & $\begin{array}{l}1.13 \dagger \\
(0.58)\end{array}$ & $\begin{array}{l}1.21 \\
(2.96)\end{array}$ & $\begin{array}{c}1.33 \\
(3.20)\end{array}$ & $\begin{array}{l}1.52 \\
(2.99)\end{array}$ & $\begin{array}{c}1.77 \\
(3.09)\end{array}$ \\
\hline $\begin{array}{l}\text { Industry Rate of Globalization } \\
\text { Change }\end{array}$ & $\begin{array}{r}1.87 \dagger \\
(1.11)\end{array}$ & & & & \\
\hline Key FDI Regulations in China & $\begin{array}{c}0.00 \\
(0.16)\end{array}$ & & & & \\
\hline Foreign Exchange Rate & $\begin{array}{l}-0.94 \dagger \\
(0.49)\end{array}$ & & & & \\
\hline Inverse Mills Ratio & & $\begin{array}{l}-2.38^{*} \\
(0.93)\end{array}$ & $\begin{array}{l}-2.41^{*} \\
(0.99)\end{array}$ & $\begin{array}{l}-2.14^{*} \\
(0.94)\end{array}$ & $\begin{array}{l}-2.33^{*} \\
(0.97)\end{array}$ \\
\hline Log- likelihood & -555.13 & -155.85 & -114.72 & -114.89 & -111.64 \\
\hline Wald Chi-square & $61.12 * * *$ & $40.43 * * *$ & $37.76^{* *}$ & $43.97 * * *$ & $40.98 * * *$ \\
\hline Number of Observations & 2248 & 379 & 379 & 379 & 379 \\
\hline
\end{tabular}

Standard error of coefficients are reported in parentheses.

$\dagger \mathrm{p}<0.10, * \mathrm{p}<0.05, * * \mathrm{p}<0.01, * * * \mathrm{p}<0.001$ (two-tailed) 


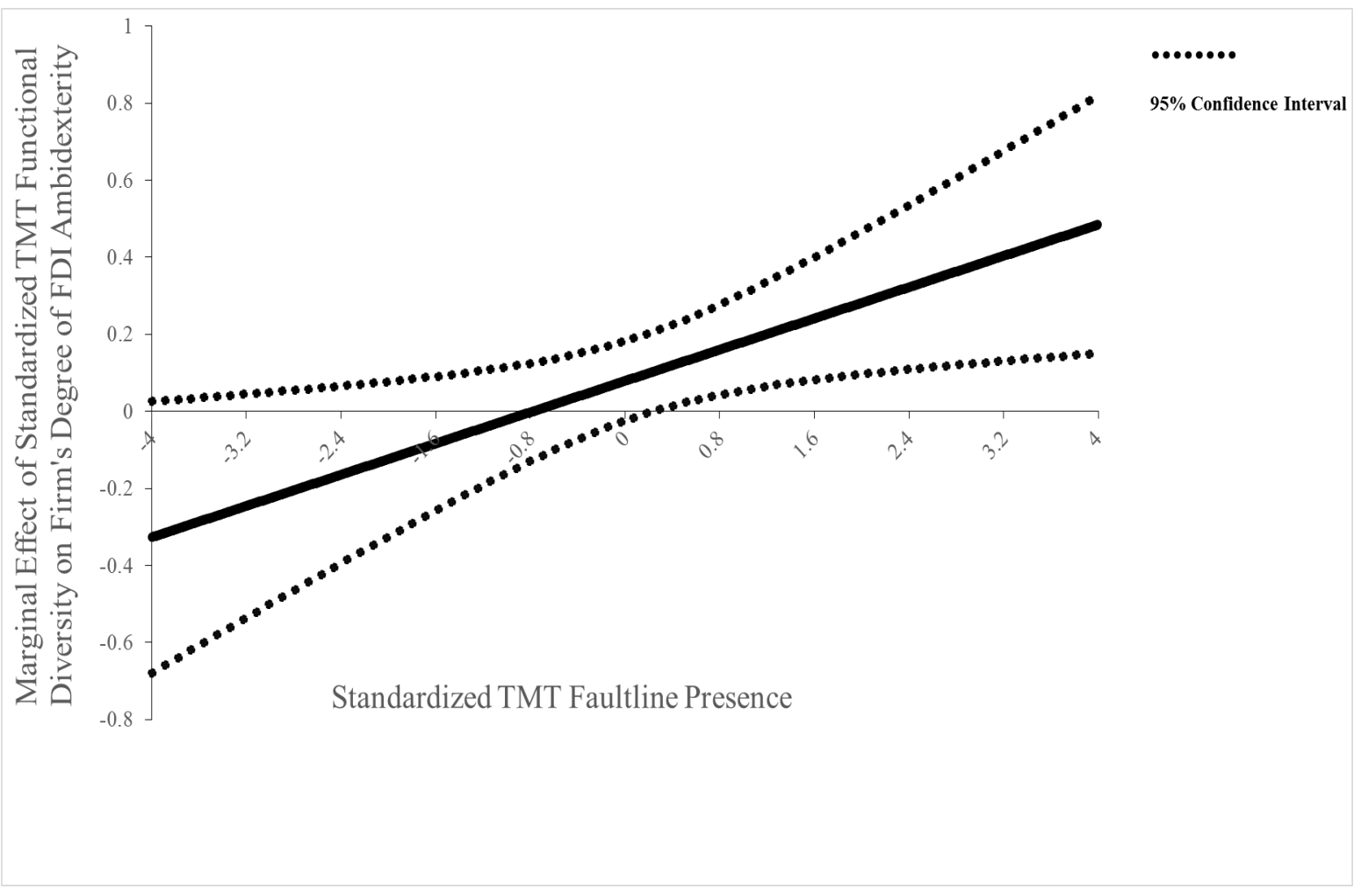

Figure 1. Moderating effect of TMT fault line presence on the link between TMT functional diversity and firm's degree of FDI ambidexterity

46 


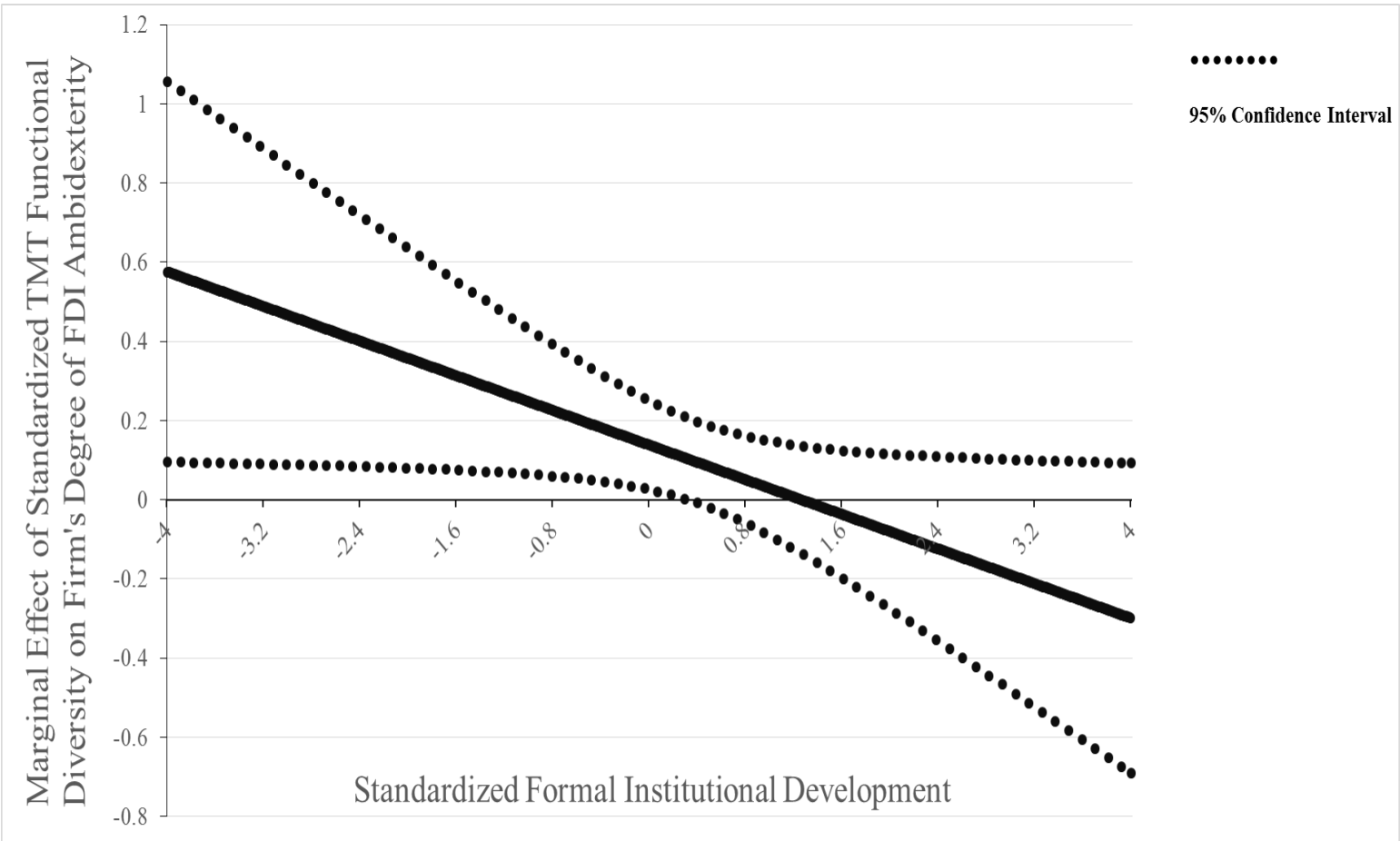

Figure 2. Moderating effect of formal institutional development on the link between TMT functional diversity and firm's degree of FDI ambidexterity 


\section{Author Biographies}

$\mathrm{Yi} \mathrm{Li}$ is a lecturer of Chinese business management in Discipline of International Business, at the University of Sydney Business School. His research interests include internationalization of firms in emerging economy, institutional approaches of business strategy, and dynamic evolution of control in international joint ventures. His work has been published or forthcoming in journals such as Organization Studies, International Business Review, Management International Review, Journal of Business Research, Technovation and others.

Lin Cui is an associate professor in international business in the Research School of Management of the Australian National University. His research centres on emerging market firms' strategies and operations, with special focus on Chinese firms. He has broad research interests in internationalization, corporate governance, knowledge transfer, and cross-cultural management. His recent research is published in Journal of International Business Studies, Organization Studies, Journal of World Business, Management and Organization Review, among others. 